\title{
The Analysis of the Causal Relationship Between Budget Balance and Current Account Balance by MGARCH Methodology: Turkey Experience
}

\author{
Bütçe Dengesi ve Cari İşlemler Dengesi Arasındaki Nedensel İlişskinin MGARCH \\ Yöntemiyle Analizi: Türkiye Deneyimi
}

\author{
Asst. Prof. Dr. Pelin Varol İyidoğan
}

\begin{abstract}
The aim of the study is to explore the causality relationship between the budget balance and the current account balance of Turkey. Differently from the literature, the causality relationship is examined by considering the volatility of the variables in question. Accordingly, the multivariate GARCH (MGARCH) methodology for modelling the volatility and 1987-2005 quarterly data of Turkey are utilized. Depending upon the results of the selection criterion and autocorrelation tests, constant conditional correlation (CCC) model is determined as the appropriate MGARCH model for the analysis. The results of the Granger causality test applied on the CCC model find no evidence that supports the effect of the budget deficit on the current account deficit. Contrarily, the current account balance is found to be influential both on the budget balance and the volatility of the budget balance. Therefore it should be considered that the policies regarding the current account balance affects the budget balance as well.
\end{abstract}

Keywords: Budget Deficit; Current Account Deficit; Volatility; GARCH; Causality.

\section{Öz}

Çalı̧smanın amacl, bütçe dengesi ve cari işlemler dengesi arasındaki ilişkinin Türkiye için araştırılmasıdır. Yazından farklı olarak, nedensel ilişki ilgili değişkenlerin volatilitesi dikkate alnnarak incelenmektedir. Bu doğrultuda, çok değişkenli GARCH (MGARCH) modeli ve Türkiye’nin 1987-2005 çeyrek verileri kullanılmaktadır. Seçim kriterleri ve otokorelasyon test sonuçlarına göre, analiz için uygun model olarak sabit koşullu korelasyon modeli belirlenmektedir. Bu modele uygulanan Granger nedensellik testinin ortaya koyduğu bulgular, bütçe dengesinin cari işlemler dengesi üzerinde etkili olmadiğını göstermektedir. Buna karşın, cari işlemler dengesi gerek bütçe dengesi gerekse bütçe dengesinin volatilitesi üzerinde belirleyici olmaktadır. $\mathrm{Bu}$ nedenle, cari işlemler dengesine yönelik politikaların aynı zamanda bütçe dengesini de etkilediği göz önünde bulundurulmalıdır.

Anahtar Kelimeler: Bütçe Açığl; Cari İ̧slemler Açığl; Volatilite; GARCH; Nedensellik.

\section{Introduction}

Analysis of the relationship between the budget balance and the current account balance, which is the basic component of the external balance, has recently become one of the important focuses in the literature. In addition that the examination of the causes and dynamics behind the current account balance is an important research subject, the role of external balance in the variations of budget balance also arouses interest. The empirical findings of the studies that examine the regarding relationship either for Turkey or for other countries employing the causality tests, point out four different possibilities: i) causality from budget balance to current account balance that is explained theoretically by three fundamental frameworks, namely the income-expenditure model, Mundell-Fleming model and the investment-saving

Asst. Prof. Dr. Pelin Varol İyidoğan, Hacettepe University Faculty of Economics and Administrative Sciences, pelinv@hacettepe.edu.tr 
relationship, ii) the absence of relation between two variables: Ricardian equivalence theorem, iii) bidirectional causality, iv) causality from current account deficit to budget deficit.

Revealing the relationship between the current account and the budget balance, which lies behind the economic crises that Turkey has experienced historically, is important in order to implement optimal economy policies. Considering the development of the budget balance in Turkish economy, it is obvious that the deficits have become persistent after 1980 and the transfer expenditures which have increased depending on the domestic and foreign debts, especially through the last years of the analysis period, have an influence towards deteriorating the consolidated budget balance. As a result of the economic measures taken following the crisis periods, the budget balance exhibits temporary recoveries. On the other hand, the current account balance, which is the other variable of the analysis, seems to adopt an unstable trend as a result of the foreign trade regime and capital movements liberalization in 1980's. Consequently, both variables of the analysis, budget balance and the current account balance, exhibit significant fluctuations throughout the sampling period. Therefore, the GARCH models, which are frequently used in modeling the volatility in the variables such as inflation, exchange rate and interest rate, become also important for modeling the budget balance or current account balance. In the literature, there are various studies performing Granger causality analysis in the GARCH model (e.g., Grier and Perry, 2000; Fountas et al., 2006; Hasanov and Omay, 2011). The importance and contribution of this study is that, it has for the first time revealed the causal relationship between the budget balance and the current account balance in Turkey by employing the multivariate GARCH (MGARCH) model.

The remainder of this paper is organized as follows. Section 1 mentions the theoretical explanation of the relationship between the budget balance and the current account balance and related empirical literature. Section 2 describes the model. In section 3, the data set and the empirical results are presented. Section 4 is concluded.

\section{The Theory and the Empirical Literature}

The alternative relationships between the budget balance and the current account balance can be based on important theoretical grounds. It is possible to explain the independency of these variables by means of the Ricardian equivalence theorem which asserts that the real impacts of the budget balance will disappear as a result of the compensation of the reduction in public savings by an increase in private savings. On the other hand, the effect of the budget balance on the current account balance is explained through three different mechanisms: the income-expenditure model, Mundell-Fleming model and the investmentsavings relationship. Within the income-expenditure model, the increase in the budget deficit increases the national income which leads to a multiplier effect. The increase in the national income promotes import, depending on the marginal propensity to import and the consequent decrease in the net export causes deterioration in the current account balance. MundellFleming model explains the concerned relationship through the interest and exchange rate mechanisms. Within the framework of the model, the increase in the budget deficit causes increase in the real interest rate, thus encourages the capital inflow. Depending on this process, appreciation of the national currency negatively affects the net export and increases the current account deficit. Finally, the investment-saving relationship is explained by (1) which is derived from the national income identity:

$$
\left(\mathrm{S}^{\mathrm{P}}-\mathrm{I}^{\mathrm{P}}\right)+(\mathrm{T}-\mathrm{G})=\mathrm{NX}
$$

In the equation, $\mathrm{S}^{\mathrm{p}}$ denotes the private sector savings while IP, T, G and NX stand for the private sector investment, taxes, government expenditures and current account balance, respectively. Therefore, the first parentheses on the left side of the equation represent the savings-investment equilibrium of the private sector and the second one represents that of the government sector. From this point forth, assuming the private sector equilibrium constant, a change in the budget balance leads to an impact with the same direction and size on the current account balance. On the other hand, according to Baharumshah et al. (2006), current account deficits end up with deterioration in fiscal balance especially in small open developing countries which finance economic growth by foreign capital inflows. Furthermore, Summers (1988) argues that the policy implementations aiming at maintaining the current account balance give rise to budget deficits.

Among the literature ${ }^{1}$, the studies widely examine the budget balance and current account balance relation by utilizing VAR analysis, cointegration and causality

1 For a detailed discussion of the literature, see Varol İyidoğan (2011). 
tests. The empirical results may be classified in four groups. First, Abell (1990), Latif-Zaman and DaCosta (1990), Bachman (1992), Rosensweig and Tallman (1993), Dibooğlu (1997), Normandin (1999), Vamvoukas (1999), Beetsma et al. (2008), Hakro (2009) find support of the budget balance affecting current account balance. Second, Kim and Kim (2006), Onafowora and Owoye (2006), Marinheiro (2008), Katırcioğlu et al. (2009), Kalou and Paleologou (2011) find evidence of causality running from the current account balance to budget balance. Third, Darrat (1988), İslam (1998), Mukhtar et al. (2007) assert the existence of bi-directional causality. Finally, Enders and Lee (1990), Kaufmann, Scharler and Winckler (2002), Datta and Mukhopadhyay (2010) conclude with the Ricardian equivalence theorem.

\section{Methodology: Multivariate GARCH Models}

In this study, the relationship between the budget deficit and the current account deficit is given a new meaning by applying MGARCH model. Through this methodology, taking also into account the effect of the volatility in the budget balance and the current account balance, the relationship is ensured to be analyzed within the framework of the uncertainty phenomenon.

Silvennoinen and Terasvirta (2008) emphasize that, the multivariate GARCH models must bear some fundamental characteristics. The first one requires the model to be flexible enough to be able to represent the dynamics of the conditional variances and covariances. The second characteristic is that, the model definition must be parsimonious enough to allow for easy estimation and interpretation in terms of the number of parameters. They finally emphasize that, the conditional variance-covariance matrix must be positive definite. Silvennoinen and Terasvirta (2008) analyze the multivariate GARCH models under four categories ${ }^{2}$. However based on the methodology used in this study, only the models included in the first two categories, particularly the constant conditional correlation model in the second category, are explained in detail. In the first category, where $\mathrm{VECH}$ and BEKK models are included, the conditional covariance matrix is modeled directly. The second category including the constant conditional correlation model,

2 These categories can be specified as the conditional covariance matrix models, conditional variance and correlations models, factor models and non-parametric and semi-parametric approaches. which is selected as the appropriate model ${ }^{3}$ for the analysis of the relationship between the budget and current account balance, and its various expansions, model the conditional variance and correlations rather than the conditional covariance matrix.

As mentioned above, there are two important factors taken into account in estimating the multivariate GARCH models. The first one is the number of unknown parameters that should be as small as possible. The second important factor is the positive definiteness of the conditional variance-covariance matrix. The models which are handled with respect to these criteria can be compared by means of Table 1 below:

The VECH and BEKK models may be basically considered as the extensions of the univariate GARCH models. These models, in parallel with the univariate GARCH models which identify the conditional variance, include the processes aiming at modeling the conditional covariance. However, these models have some inadequacies due to the difficulty of ensuring the positive definiteness of the covariance matrix and the complexity of the estimation process regarding the increase in the number of the unknown parameters with the increase in the number of variables. On the other hand, the models modeling the conditional correlations ${ }^{4}$ assign secondary importance to the dynamics of the conditional covariances and largely compensate the shortcomings of such models.

Correlation models are based on the decomposition of the conditional covariance matrix into conditional standard deviations and correlations. The constant conditional correlation model of Bollerslev (1990) constitutes a basis to the multivariate correlation models.

Under the assumption of the constancy of the conditional correlation $\left(\mathbf{r}_{i j}\right), \quad \mathbf{r}_{i j}=h_{i j t} / \sqrt{h_{i i t} h_{j j t}}$ is obtained. Here, the constant conditional correlation is defined as the ratio of the conditional covariances to the square root of the multiplication of the con-

ditional variances. $r_{i j}$, which is calculated through the standardized error terms and marginal GARCH models, enables identification of the time-variant covariances.

3 See Table 4.

4 For a detailed explanation of the conditional correlation mode els and constant conditional correlation model, see the study of Jondeau, Poon and Rockinger (2007, p. 206-207). 
Table 1. The comparison of MGARCH models

\begin{tabular}{|l|l|l|}
\hline Model & $\begin{array}{l}\text { Number of unknown } \\
\text { parameters }\end{array}$ & Positive definiteness \\
\hline VECH & $(p+q)\left[\frac{N(N+1)}{2}\right]^{2}+\frac{N(N+1)}{2}$ & $(-)$ \\
\hline DVECH & $(p+q)\left[\frac{N(N+1)}{2}\right]+\frac{N(N+1)}{2}$ & $(-)$ \\
\hline BEKK & $(p+q) N^{2}+\frac{N(N+1)}{2}$ & $(+)$ \\
\hline DBEKK & $(p+q) N+\frac{N(N+1)}{2}$ & $(+)$ \\
\hline CCC & $(p+q+1) N+\frac{N(N+1)}{2}$ & $(+)$ \\
\hline
\end{tabular}

Source: Author's construction.

Notes: i) (-)and (+) signs indicate the negative and positive defineteness, respectively. ii) DVECH denotes diagonal VECH model and DBEKK presents diagonal BEKK model. iii) $\mathrm{p}$ and $\mathrm{q}$ indicate the lengths in the conditional covariance matrix and $\mathrm{N}$ signifies the number of variables that are modeled by the multivariate GARCH model.

$$
h_{i j t}=\mathrm{r}_{i j} \times \sqrt{h_{i i t} h_{j j t}}
$$

Considering (2), it is possible to define the general form of the n-variable constant conditional correlation. Bollerslev (1990) expresses the time-invariant correlation matrix as follows:

$$
R=\left[\begin{array}{cccc}
1 & \mathrm{r}_{12} & \ldots & \mathrm{r}_{1 n} \\
\mathrm{r}_{12} & 1 & & \vdots \\
\vdots & \ddots & \ddots & \vdots \\
\mathrm{r}_{1 n} & \ldots & \mathrm{r}_{n, 1-n} & 1
\end{array}\right]
$$

From this point, the full conditional covariance matrix is defined as follows:

$$
H_{t}=D_{t}^{1 / 2} R D_{t}^{1 / 2}
$$

As $D_{t}$ represents the diagonal matrix of the conditional variances, modeling the dynamics of the $\mathrm{n}$ conditional variances and estimating the constant conditional correlation matrix is sufficient. Since the model reduces the number of parameters to be estimated to $\mathrm{N}(1+\mathrm{p}+\mathrm{q})+\mathrm{N}(\mathrm{N}+1) / 2$ and also ensures the positive definiteness of the conditional covariance matrix, it is frequently employed in the literature owing to these advantages. However, the model is criticized due to its constant correlation assumption and at this point, the models allowing for the use of time-variant correlations take precedence. One of such models that are frequently used is the dynamic conditional correlation (DCC) model introduced by Engle (2002) and Engle and Sheppard (2001). Since this model is not used in the study, it is not detailed.

\section{Data and empirical results}

The relationship between internal and external balance of Turkey is examined by using 1987:1-2005: $4^{5}$ data for the budget balance/GDP (bb) and current account balance/GDP (ca) series. The budget balance, current account balance and GDP series have been generated by means of the data which is obtained from the Ministry of Finance General Directorate of Accounting, CBRT Electronic Data Distribution System and Turkish Statistical Institute, respectively.

In the study, firstly the results of the unit root analysis are reported to assess stationarity of the seasonally adjusted series. Table 2 includes the results of the ADF (Augmented Dickey Fuller) and PP (PhilipsPerron) unit root tests.

5 The reason for the data not being up-to-date is the change of the budget definition in 2006. Accordingly, while consolidated budget implementation was in question between 1994-2005, central government budget has begun to be used since 2006 . Since the harmonization of these two practices has not been completed yet, the analyses in the study is employed using the data of 1987:1-2005:4 
Table 2. Unit Root Test Results

\begin{tabular}{|l|l|l|}
\hline & ADF & PP \\
\hline Current account balance & $-4.18(0)^{*}$ & $-4.34(3)^{*}$ \\
\hline Budget balance & $-4.95(0)^{*}$ & $-5.07(4)^{*}$ \\
\hline
\end{tabular}

Notes: (i) The parentheses indicate the appropriate lag lengths for the ADF regressions and the appropriate bandwidths for the PP regressions. The lags are determined by Schwarz information criteria (SIC) (ii) ${ }^{*}$ denotes that the test statistics are significant at $1 \%$ level.

The unit root analysis of the study deduces that, either according to ADF test or to PP test, both series are stationary at the level of $1 \%$. In the next step, considering the selection criteria in Table 3, the appropriate lag length ( $\mathrm{p})$ is determined and the VAR model

$$
\begin{aligned}
& c a_{t}=\phi_{0}+\sum_{i=1}^{p} \phi_{i} c a_{t-i}+\sum_{i=1}^{p} \gamma_{j} b b_{t-i}+\varepsilon_{1 t} \\
& b b_{t}=\beta_{0}+\sum_{i=1}^{p} \beta_{i} c a_{t-j}+\sum_{i=1}^{p} \delta_{j} b b_{t-j}+\varepsilon_{2 t}
\end{aligned}
$$

Table 3. The Selection of Unrestricted VAR(p) Model

\begin{tabular}{|l|l|l|l|l|}
\hline Lag length & LR & AIC & SIC & HQ \\
\hline 0 & - & -7.05 & -6.98 & -7.02 \\
\hline 1 & 75.05 & -8.04 & $-7.85^{*}$ & -7.96 \\
\hline 2 & 12.76 & -8.12 & -7.80 & -7.99 \\
\hline 3 & 4.06 & -8.07 & -7.62 & -7.89 \\
\hline 4 & 5.01 & -8.04 & -7.47 & -7.81 \\
\hline 5 & $22.85^{*}$ & $-8.31^{*}$ & -7.61 & $-8.02^{*}$ \\
\hline
\end{tabular}

Notes: i) * presents optimal lag length. ii) LR, AIC, SIC and HQ show likelihood ratio, Akaike information criteria, Schwarz information criteria and Hannan-Quinn criteria.

According to Table 3, although the VAR(1) model stands out with regard to the SIC, the analysis is performed by using the VAR(5) model that is selected by the AIC and HQ since the autocorrelation is detected in the VAR(1) model. The residual diagnostic tests, Ljung-Box portmanteau tests for autocorrelation and multivariate normality tests, are also performed in the VAR(5) model in order to check the absence of non-normality and serial correlation. It is concluded that the VAR(5) model has no residual autocorrelations up to lag 8 and the residuals are multivariate normal since the null hypotheses of normality and no autocorrelation are accepted. After the selection of the appropriate VAR model, the next step includes the determination of VAR-GARCH structure. In this regard, the data in the Table 4 is used in order to make selection between the models with alternative VARGARCH structure.

Table 4. The Selection of VAR-GARCH Model
\begin{tabular}{|l|l|l|l|}
\hline Model & AIC & SIC & HQ \\
\hline VAR 5-diagonal VECH-GARCH(1,1) & -8.55 & -7.56 & -8.16 \\
\hline VAR 5-CCC-GARCH(1,1) & $\mathbf{- 8 . 5 9}$ & $\mathbf{- 7 . 5 8}$ & $\mathbf{- 8 . 1 7}$ \\
\hline VAR 5-diagonal BEKK-GARCH(1,1) & -8.40 & -7.48 & -8.04 \\
\hline
\end{tabular}

The selection between the estimated conditional covariance matrix models and conditional correlation models is made considering AIC, SIC and HQ. Consequently, the $\operatorname{VAR}(5)-\mathrm{CCC}-\mathrm{GARCH}(1,1)$ model with the lowest values and so which can be regarded as ideal according to the mentioned criteria is selected. The estimation of the model follows as in Table 5: 


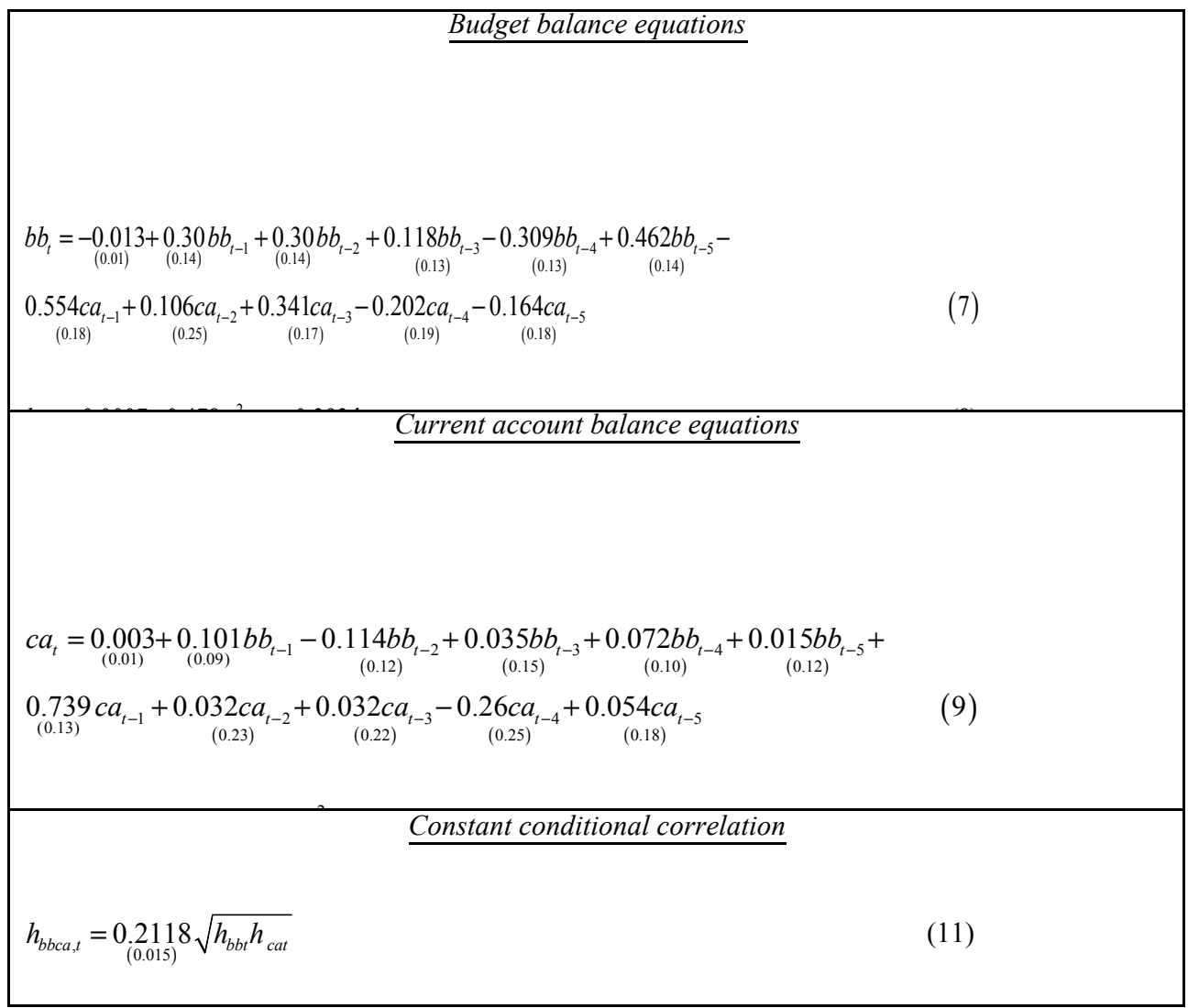

Note: The values in brackets denote standard errors.

According to Table 5, the sum of estimated current account balance coefficients is 0,635 in (7) while the sum of lagged budget balance coefficients is 0.109 in (9). The ARCH parameters are estimated as 0.478 and 0.132 for the budget and the current account balance equation, respectively. On the other hand, the GARCH parameters are found to be statistically significant and estimated as 0,392 for the budget balance and 0.862 for the current account balance that are less than 1. In this case, GARCH parameter which is smaller than the ARCH parameter shows that the short term effect of a shock will be much higher than the long term for the budget balance. On the other hand, the GARCH parameter greater than the $\mathrm{ARCH}$ parameter indicates the vice versa for the current account balance. The sum of the ARCH and GARCH parameters for the budget balance and the current account balance that are found to be 0,87 and 0,994 , respectively points out the importance of current information in the forecast of the conditional variances for long horizons.

As the residual diagnostic test for the VAR(5)-CCCGARCH $(1,1)$ model, the Ljung-Box Q statistics are calculated. The results indicate that the regarding model has no residual autocorrelations up to lag 8 as reported in Table 6. Moreover, the residuals are multivariate normal since the JB test statistic (5.79) leads to the non-rejection of the normality null hypothesis.

In the last step of the analysis, by choosing an appropriate lag length for the bivariate $\operatorname{GARCH}(1,1)$ model estimated above, Granger causality analysis is performed and the results are given in the Table 7. 
Table 6. Residual Diagnostics

\begin{tabular}{|l|l|l|l|l|}
\hline Lags & Q-stat & p-value & Adj.Q-stat & p-value \\
\hline 1 & 2.52 & 0.64 & 2.55 & 0.63 \\
\hline 2 & 5.33 & 0.72 & 5.45 & 0.71 \\
\hline 3 & 6.05 & 0.91 & 6.19 & 0.91 \\
\hline 4 & 9.69 & 0.88 & 10.05 & 0.86 \\
\hline 5 & 12.95 & 0.87 & 13.57 & 0.85 \\
\hline 6 & 13.21 & 0.96 & 13.84 & 0.95 \\
\hline 7 & 14.89 & 0.97 & 15.72 & 0.96 \\
\hline 8 & 21.82 & 0.91 & 23.53 & 0.86 \\
\hline
\end{tabular}

Note: The table shows Ljung-Box test statistics and the probabilities.

\section{Table 7. Granger-Causality Test Results}

\begin{tabular}{|c|c|c|c|}
\hline & Lag 1 & Lag 4 & Lag 8 \\
\hline 1) $\mathrm{ca} \rightarrow \mathrm{bb}$ & $5.52115 * *(-)$ & $2.341403^{* * *}(-)$ & $2.624873 * *(-)$ \\
\hline 2) $\mathrm{ca} \rightarrow \operatorname{var}(\mathrm{ca})$ & $18.8840 *(-)$ & $8.07587^{*}(-)$ & $4.44227^{*}(-)$ \\
\hline 3) $\mathrm{ca} \rightarrow \operatorname{var}(\mathrm{bb})$ & $4.63686^{* *}(+)$ & $11.9160 *(+)$ & $5.59776^{* *}(+)$ \\
\hline 4) $\mathrm{bb} \rightarrow \mathrm{ca}$ & $1.83143(+)$ & $1.66382(+)$ & $0.4542(+)$ \\
\hline 5) bb $\rightarrow \operatorname{var}(\mathrm{ca})$ & $0.95157(-)$ & $0.69857(+)$ & $0.63689(+)$ \\
\hline 6) $\mathrm{bb} \rightarrow \operatorname{var}(\mathrm{bb})$ & $0.16406(-)$ & $2.45613 * *(-)$ & $1.32669(-)$ \\
\hline 7) $\operatorname{var}(\mathrm{ca}) \rightarrow \mathrm{ca}$ & $0.68425(+)$ & $0.44701(+)$ & $1.28794(+)$ \\
\hline 8) $\operatorname{var}(c a) \rightarrow b b$ & $0.27649(+)$ & $0.34885(+)$ & $0.18773(+)$ \\
\hline 9) $\operatorname{var}(\mathrm{ca}) \rightarrow \operatorname{var}(\mathrm{bb})$ & $2.68840(+)$ & $0.82402(+)$ & $0.74456(+)$ \\
\hline 10) $\operatorname{var}(\mathrm{bb}) \rightarrow \mathrm{ca}$ & $0.04676(+)$ & $1.02936(-)$ & $0.75219(-)$ \\
\hline 11) $\operatorname{var}(\mathrm{bb}) \rightarrow \mathrm{bb}$ & $2.73601 * * *(-)$ & $3.27806 * *(-)$ & $1.24617(-)$ \\
\hline 12$) \operatorname{var}(\mathrm{bb}) \rightarrow \operatorname{var}(\mathrm{ca})$ & $2.70798(-)$ & $0.57438(-)$ & $0.48075(-)$ \\
\hline
\end{tabular}

Notes: i) The terms in bold show the appropriate lag lengths chosen by the selection criterion (AIC and SIC) and LM autocorrelation tests. ii) ${ }^{*},{ }^{* *},{ }^{* *}$ denote the significance at $1 \%, 5 \%$ and $10 \%$. level, respectively. iv) (+) and (-) signify positive and negative causality, respectively.

The results from Table 7 reveal that, the improvement either in the current account balance or the budget balance reduces the uncertainty of the variables. Furthermore, it is concluded that, the increase in the volatility of the budget balance adversely affects the internal balance and the volatility of the current account balance has a positive effect on the external balance. In Turkish economy, the improvement in the current account balance following fluctuation periods, may confirm this result. The results, evaluated apart from the volatility of the variables, show that a significant causality relationship from budget deficit towards current account deficit is not in question for the considered period. On the contrary, the results support that, for the period analyzed for Turkey, the current account balance is an important variable which determines the budget balance. More clearly, the evaluation of the significant causality rela- tionships verifies that the current account balance has a crucial role in explaining either the budget deficit or the volatility in the budget deficit. The direction of the causality has been determined as negative for the first relationship from current account balance to budget balance emerged at the eighth lag, and as positive for the other relation from current account balance to the volatility of budget balance that became significant at the fourth lag. Therefore, increase in the current account deficits in Turkey improves the budget balance and reduces the volatility in the fiscal balance.

As stated above ${ }^{6}$, although the data set goes back to the year 2006 as a result of the change of the budget definition in Turkey, considering the current progress of the Turkish economy, the developments recorded

6 For explanations related to the data set, see section 3 . 
are in parallel with the results obtained for the period of analysis. While on the one hand the current account deficit increases significantly, on the other hand the budget balance exhibits a stable structure and the deficits decrease. This result can be attributed to the increase in the tax revenues from consumption and foreign trade as a result of high growth rate which is partly originated from the deterioration in the current account balance. In other words, within the framework of the economic structure in which the growth of production and hence the growth of economy is dependent on the import of raw material and investment goods, the deficit in the foreign trade account becomes the most important component of the deterioration in the current account balance. Thus, the current account balance and growth exhibit movements opposite to each other. Such that, while the deterioration in external balance motivates growth, it causes an effect which increase the tax revenues.

\section{Concluding Remarks}

In Turkey, either the budget balance or the current account balance exhibits significant fluctuations which depend on the economic situation and the policy implementations by periods. Therefore, in order to be able to make an accurate empirical analysis of Turkish economy and accordingly implement the appropriate economic policies, in addition to the relationship between the variables, the causality concerning the volatility of the variables must also be analyzed. In this study which employs the multivariate GARCH model for this purpose, no empirical evidence supporting the effect of internal deficits on the external balance has been obtained. On the other hand, the determinative characteristic of the external balance is found to be more crucial since either the budget balance or the volatility in the budget balance is affected by the current account balance. Thus, the policies intended the current account balance also contributes to fiscal discipline and stability. The direction of the relationship shows that the policies toward improving the current account balance increase the budget deficit and the volatility in the budget balance. Therefore, although it is compulsory to recover the deterioration in the current account balance, which has become a chronic problem for Turkey, it must not be ignored that it has an opportunity cost against the budget balance. In order to resolve the current account imbalances, it is compulsory to implement long term policies which encourage the technological investments and target to change the import-dependent production structure. In addition, measures restricting the consumption oriented credits, which lie behind the current account deficits in Turkey, must be taken in the short term.

\section{References}

Abell, J.D. (1990). Twin Deficits During the 1980's: An Empirical Investigation. Journal of Macreconomics, 12(1), 81-96.

Bachman, D.D. (1992). Why Is the Current Account Deficit So Large? Evidence From Vector Autoregressons. Southern Economic Journal, 59(2), 232240.

Baharumshah, A.Z., Lau E. \& Khalid A. (2006). Testing Twin Deficits Hypothesis Using VARs and Variance Decomposition. Journal of the Asia Pacific Economy, 11(3), 331-354.

Beetsma, R., Giuliodori, M., \& Klaassen, F. (2008). The Effects of Public Spending on Trade Balances in the European Union. Journal of the European Economic Association, 6(2-3), 1-25.

Bollerslev, T. (1990). Modelling the Coherence in Short-Run Nominal Exchange Rates: A Multivariate Generalized ARCH Model. Review of Economics and Statistics, 72, 498-505.

Darrat, A.F. (1988). Have Large Budget Deficits Caused Rising Trade Deficits. Southern Economic Journal, 54(4), 879-887.

Datta, K. \& Mukhopadhyay, C.K. (2010). Twin Deficits Phenomenon in Maldives: Spectral and Time Domain Analysis of Time Series, The IUP Journal of Applied Economics, 9, 98-125.

Dibooğlu, S. (1997). Accounting for US Current Account Deficits: An Empirical Investigation. Applied Economics, 29, 787-793.

Enders, W. \& Lee, B.S. (1990). Current Account and Budget Deficits: Twin or Distant Cousins? Review of Economics and Statistics, 72, 373-381.

Engle, R.F. (2002). Dynamic Conditional Correlation: A Simple Class of Multivariate Generalized Autoregressive Conditional Heteroskedasticity Models. Journal of Business and Economic Statistics, 20, 339- 350. 
Engle, R.F., \& Sheppard, K. (2001). Theoretical and Empirical Properties of Dynamic Conditional Correlation Multivariate GARCH. NBER Working Paper 8554,Cambridge: The National Bureau of Economic Research.

Fountas, S., Karanasos, M. \& Kim, J. (2006). Inflation Uncertainty, Output Growth Uncertainty and Macroeconomic Performance. Oxford Bulletin of Economics and Statistics, 68(3), 319-343.

Grier, K.B. \& Perry, M.J. (2000). The Effects of Real and Nominal Uncertainty of Inflation and Output Growth: Some GARCH-M Evidence. Journal of Applied Econometrics, 15, 45-58.

Hakro, A.N. (2009). Twin Deficits Causality LinkEvidence From Pakistan. International Research Journal of Finance and Economics, 24, 54-70.

Hasanov, M. \& Omay, T. (2011). The Relationship Between Inflation, Output Growth and Their Uncertainties: Evidence From Selected CEE Countries. Emerging Markets Finance and Trade, 47, 5-20.

Islam, M.F. (1998). Brazil's Twin Deficits: An Empirical Examination. Atlantic Economic Journal, 26(2), 121-129.

Jondeau, E., Poon, S., \& Rockinger, M. (2007). Financial Modeling Under Non-Gaussian Distributions. New York, USA: Springer Finance.

Kalou, S., \& Paleologou S-M. (2011). The Twin Deficits Hypothesis: Revisiting an EMU Country. Journal of Policy Modelling, 34, 230-241.

Katırcıoğlu, S.T., Feth, S., \& Feth, M.D. (2009). Twin Deficits Phenomenon in Small İslands: An Empirical Investigation by Panel Data Analysis. Applied Economics Letters, 16(15), 1569-1573.

Kaufmann, S., Scharler, J. \& Winckler, G. (2002). The Austrian Current Account Deficit Driven by Twin Deficits or by Intertemporal Expenditure Allocation? Empirical Economics, 27, 549-542.

Kim, C-H., \& Kim D. (2006). Does Korea Have Twin Deficits?. Applied Economic Letters, 13, 675-680.
Latif-Zaman, N., \& DaCosta, M.N. (1990). The Budget Deficit and the Trade Deficit: Insights Into This Relationship. Eastern Economic Journal, 16(4), 349-354.

Marinheiro, C.F. (2008). Ricardian Equivalence, Twin Deficits, and the Feldstein-Horioka Puzzle in Egypt. Journal of Policy Modeling 30, 1041-1056.

Mukhtar, T., Zakaria, M., \& Ahmed, M. (2007). An Empirical Investigation for the Twin Deficit Hypothesis in Pakistan. Journal of Economic Cooperation, 28(4), 63-80.

Normandin, M. (1999). Budget Deficit Persistence and the Twin Deficit Hypothesis. Journal of International Economics, 49, 171-193.

Onafowora, O.A., \& Owoye, O. (2006). An Empirical Investigation of Budget and Trade Deficits: The Case of Nigeria. The Journal of Developing Areas, 39(2), 153-174.

Rosensweig, J.A., \& Tallman, E.W. (1993). Fiscal Policy and Trade Adjustment: Are The Deficits Really Twins?. Economic Inquiry, 31, 580-594.

Silvennoinen, A., \& Terasvirta, T. (2008). Multivariate Garch Models. SSE/ EFI Working Paper Series in Economics and Finance, 669, In Eds. Andersen T.G., Davis R.A., Kreiss J.-P. \& Mikosch T., Handbook of Financial Time Series, New York: Springer.

Summers, L.H. (1988). Tax Policy and International Competitiveness, in J. Frenkel, (Ed) International Aspects of Fiscal Policies, 349-375, Chicago: UP.

Telatar, E. (2011). Türkiyede Cari Açık Belirleyicileri ve Cari Açık-Krediler İlişkisi. Bankacılar Dergisi, 78, 22-34, İstanbul: Türkiye Bankalar Birliği.

Vamvoukas, G.A. (1999). The Twin Deficits Phenomenon: Evidence from Greece. Applied Economics, 31, 1093-1100.

Varol İyidoğan, Pelin (2011). İkiz Açıklar Hipotezi: Türkiye Deneyimi. (Unpublished Ph.D. Thesis). Hacettepe University/Graduate School of Social Sciences, Ankara. 